Copyright by the Cambridge University Press. Rowe, R. V. A.; Kunita, M. H.; Porto, M. F.; Muniz, E. C.; Rubira, A. F.; Nery, R. C.; Radovanovic, E.; Taylor, L. T.; Nazem, N., "Low-resistance films of polyimides with impregnated copper sulfide," J. Mater. Res., Vol. 16, No. 11, Nov 2001, 3097-3106. DOI: 10.1557/jmr.2001.0427

\title{
Low-resistance films of polyimides with impregnated copper sulfide
}

\author{
R.V.A. Rowe, M.H. Kunita, M.F. Porto, E.C. Muniz, and A.F. Rubira ${ }^{\text {a) }}$ \\ Departamento de Química, Universidade Estadual de Maringá, Av. Colombo 5790, 87020-900 \\ Maringá-Pr, Brazil \\ R.C. Nery \\ Departamento de Fisica, Universidade Estadual de Maringá, Av. Colombo 5790, 87020-900 \\ Maringá-Pr, Brazil \\ E. Radovanovic \\ Instituto de Química, Unicamp, C. Postal 3154, Campinas, SP, Brazil \\ L.T. Taylor and N. Nazem \\ Department of Chemistry, Virginia Tech, Blacksburg, Virginia 24061
}

(Received 20 February 2001; accepted 9 August 2001)

Surface modification of polyimides has been used to obtain better interaction with an inorganic material. Copper sulfide incorporation onto the surface of commercial Kapton ${ }^{\circledR}$ polyimide showed that treatment with base was necessary for adherence of the copper sulfide to the polymeric matrix. The optimized conditions for composite preparation, obtained by response surface methodology, was $\mathrm{pH} 1.4$ at $80{ }^{\circ} \mathrm{C}$ for $3.67 \mathrm{~h}$. Using these conditions, we obtained electrical resistance as low as $1.0 \mathrm{ohm}$ for CuS\Kapton ${ }^{\circledR}$ composites. These optimized conditions were used to prepare other low-resistance polyimide composites. The resulting composites were analyzed by photoelectron spectroscopy. The presence of $\mathrm{S}(2 p)$ and $\mathrm{Cu}(2 p)$ peaks demonstrated the incorporation of copper sulfide onto the polyimide surface. Scanning electron microphotographs and the images from atomic force microscopy showed a homogeneous $\mathrm{CuS}$ distribution in all composites.

\section{INTRODUCTION}

Polyimides (PI) have found wide applications in the electronics industry as well as in areas such as sensor technology, optical fibers, gas separation membranes, and the medical field. Applications in microelectronics ${ }^{1}$ include use as an interlayer dielectric in integrated circuits, intermetal insulators in multichip modules, and thermal-mechanical passivation buffer protection layers. $^{2,3}$ Kapton $^{\circledR}$, poly[ $N, N^{\prime}$-(oxydiphenylene)pyromellitimide], is a polyimide with high-temperature resistance, good mechanical properties, high flame resistance, good dimensional stability, and low dielectric constant. ${ }^{4}$

The properties of polyimide film can be modified by the incorporation of a variety of inorganic additives. Ideally, doped polyimide films would retain the polymer's strength, flexibility, and thermal stability but also exhibit

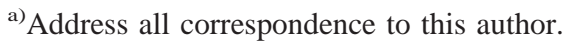

enhanced electrical conductivity and specular reflectivity. Polyimide composite films have been previously synthesized by thermal imidization of a polyamic acid solution which contained a soluble additive. ${ }^{5}$ Reliable adhesion between the metallization and the insulating polyimide layer in these films should depend on the nature of interaction between the metal and the polymer. Metal/polymer bond formation is expected to result in a strong adhesion, whereas, a purely physical interaction via van der Waals or electrostatic forces is supposed to result in weak adhesion. ${ }^{6}$

Many surface-treatment methods have been developed to increase the interfacial strength between metals and polyimide film. These include ion beam and plasma treatment methods using as starting gases water, argon, oxygen, and oxygen-fluorocarbon mixtures. These processes are effective by altering the chemical structure of the surface to cause chemical bonding at the interface or by roughening the surface of the film to cause mechanical interlocking with the next layer. The modification of 
a polyimide surface with a solution of moderate basicity has also been shown to improve the adhesion between polyimide and metal. $^{7-9}$

The deposition of metal sulfide as fine particles onto the surface of an organic polymer film is a promising approach to obtain electrically conductive films. Although this method has the advantage of giving largesize electrically conductive films, there have been only a few reports ${ }^{10,11}$ on the subject, probably due to difficulty in obtaining a good adhesion between sulfide layer and polymer film surface. Films of poly(ethylene terephthalate) (PET), poly(vinyl alcohol) (PVA), and poly(2cyano-1,3-phenylene oxide) (ID-300) have yielded surface electrically conducting films with copper sulfide. These $\mathrm{Cu}_{x} \mathrm{~S}$-polymer films have been utilized in optoelectrical reactions. ${ }^{10}$ Electrical and optical properties of poly(methyl methacrylate) sheets coated with chemically deposited $\mathrm{Cu}_{x} \mathrm{~S}$ thin films have also been described. ${ }^{11}$ Sheet resistance of the films was found to be a function of the deposition method, annealing time, and annealing temperature.

The preparation of electrically conductive $\mathrm{Cu}_{x} \mathrm{~S}-\mathrm{PI}$ films by deposition of copper sulfide from aqueous solution onto a polyimide film surface is reported in this paper. To determine optimum conditions for obtaining these films, we used the response surface methodology $(\mathrm{RSM}){ }^{12,13}$

\section{EXPERIMENTAL}

Kapton ${ }^{\circledR}$ polyimide films was obtained from Polymer Solutions Incorporated (Blacksburg, VA). All the other polyimides films were synthesized as described elsewhere. ${ }^{14} \mathrm{CuSO}_{4} \cdot 5 \mathrm{H}_{2} \mathrm{O}, \mathrm{Na}_{2} \mathrm{~S}_{2} \mathrm{O}_{3} \cdot 5 \mathrm{H}_{2} \mathrm{O}, \mathrm{H}_{3} \mathrm{PO}_{4}$, $\mathrm{NH}_{4} \mathrm{OH}$, and $\mathrm{N}, \mathrm{N}$-dimethylacetamide (DMAC) were obtained from Aldrich Chemical Co. (Milwaukee, WI) and used as received.

Poly(amide acid) solutions were prepared at room temperature by first adding diamine $(4.0 \mathrm{mmol})$ to a nitrogen-purged three-neck flask containing dry DMAc with agitation. Next, dianhydride $(4.0 \mathrm{mmol})$ was added to the solution, with an additional amount of DMAc for obtaining the desired solids concentration. The resultant solution was stirred for at least $2 \mathrm{~h}$. The imidized films were then produced by spreading the polymer solution with a doctor blade (16-20 mil gap) onto a glass plate, followed by heating $20 \mathrm{~min}$ at $80{ }^{\circ} \mathrm{C}$, and then heating at 100,200 , and $300^{\circ} \mathrm{C}$ each for $1 \mathrm{~h}$ under a dynamic 30 standard cubic feet per hour atmosphere of dry breathing air (Air Products and Chemicals, Inc., Allentown, PA). After being cooled at room temperature, the films were removed from the glass plate for testing.

\section{A. Preparation of copper sulfide deposited polyimide film}

Initially, the surface of a polyimide was modified by immersion of the film into $1 \mathrm{M} \mathrm{NH}_{4} \mathrm{OH}$ for $30 \mathrm{~min}$ at $80^{\circ} \mathrm{C}$. The resulting film was then washed with water and dried for $4 \mathrm{~h}$ at approximately $60^{\circ} \mathrm{C}$. The surface modified film was next dipped into an aqueous solution $(80 \mathrm{~mL})$ of a mixture of $0.1 \mathrm{M} \mathrm{CuSO}_{4} \cdot 5 \mathrm{H}_{2} \mathrm{O}$ and $0.1 \mathrm{M}$ $\mathrm{Na}_{2} \mathrm{~S}_{2} \mathrm{O}_{3} \cdot 5 \mathrm{H}_{2} \mathrm{O}$, and the medium was heated under agitation and temperature control. A factorial design experimental approach was applied to quantitatively assess the influence of immersion time, temperature, and solution $\mathrm{pH}$ on incorporation of copper sulfide onto the polyimide. A $2^{3}$ factorial design which included a central point and three levels of each variable was employed. A Box-Behnken ${ }^{12}$ design was used as described in Table I.

\section{B. Measurements}

Thermal analysis for the purpose of determining the glass transition temperature was performed on a Shimadzu model 50 (Tokyo, Japan) differential scanning calorimeter at $10{ }^{\circ} \mathrm{C} / \mathrm{min}$ heating rate under a nitrogen atmosphere. To determine the composite decomposition temperature, thermogravimetric analysis was performed on a Shimadzu model 50 thermogravimetric system at $10{ }^{\circ} \mathrm{C} / \mathrm{min}$ heating rate with dynamic nitrogen.

X-ray photoelectron spectra (XPS) were obtained with a Perkin-Elmer Phi model 5300 ESCA (Eden Praire, $\mathrm{MN})$ system using a magnesium anode $\left(\mathrm{K}_{\alpha}=1253.6 \mathrm{eV}\right)$

TABLE I. Electrical resistance values of CuS/Kapton ${ }^{\circledR}$ composites obtained from an initial $2^{4}$ factorial design.

\begin{tabular}{rcccrr}
\hline \hline Film & $\begin{array}{c}\text { Pretreatment } \\
\text { of the film }\end{array}$ & $\begin{array}{c}\text { Temperature } \\
\left({ }^{\circ} \mathrm{C}\right)\end{array}$ & Time $^{\mathrm{c}}(\mathrm{h})$ & $\mathrm{pH}^{\mathrm{d}}$ & $\begin{array}{r}\text { Electrical } \\
\text { resistance } \\
(\text { ohms })\end{array}$ \\
\hline 1 & w & 50 & 1 & 1 & $>10000$ \\
2 & wo & 50 & 1 & 1 & $>10000$ \\
3 & w & 80 & 1 & 1 & 10 \\
4 & wo & 80 & 1 & 1 & 190 \\
5 & w & 50 & 3 & 1 & 1800 \\
6 & wo & 50 & 3 & 1 & $>10000$ \\
7 & w & 80 & 3 & 1 & 20 \\
8 & wo & 80 & 3 & 1 & 30 \\
9 & w & 50 & 1 & 3 & $>10000$ \\
10 & wo & 50 & 1 & 3 & $>10000$ \\
11 & w & 80 & 1 & 3 & 7 \\
12 & wo & 80 & 1 & 3 & 15 \\
13 & w & 50 & 3 & 3 & 1200 \\
14 & wo & 50 & 3 & 3 & $>10000$ \\
15 & w & 80 & 3 & 3 & 1 \\
16 & wo & 80 & 3 & 3 & 40 \\
\hline \hline
\end{tabular}

a'Levels: wo (+), w (-).

${ }^{b}$ Levels: $80{ }^{\circ} \mathrm{C}(+), 50{ }^{\circ} \mathrm{C}(-)$.

cLevels: $3 \mathrm{~h} \mathrm{(+),} 1 \mathrm{~h}(-)$.

${ }^{\mathrm{d} L e v e l s: ~} 3(+), 1(-)$. 
operating at $400 \mathrm{~W}$. The binding energies cited here are referenced to the aromatic carbon photopeak $\mathrm{C}(1 s)$ of the polyimide backbone at $284.6 \mathrm{eV}$.

Scanning electron microphotographs (SEM) were taken using a JEOL JSM-6340F (Tokyo, Japan) field emission scanning electron microscope (FESEM). Surface images were taken using a Topometrix model Discover TMX2010 atomic force microscope. Surface electrical resistance at room temperature was measured using a Keithley (Cleveland, $\mathrm{OH}$ ) voltage supply (model $240 \mathrm{~A}$ ), electrometer (model 617C), and a four-point probe assembly.

Photoacoustic infrared spectra (PAS-FTIR) of the original and pretreated polyimide films in the 4000$400 \mathrm{~cm}^{-1}$ range were acquired using a Bomen FT-IR model MB100 (Quebec, Canada) with a photoacoustic apparatus model PAS MTEC 300.

\section{RESULTS AND DISCUSSION}

The heating of an aqueous solution containing an equimolar mixture of $\mathrm{CuSO}_{4}$ and $\mathrm{Na}_{2} \mathrm{~S}_{2} \mathrm{O}_{3}$ results in the production of mixtures of copper sulfides. ${ }^{10}$ Copper sulfide incorporation onto the surface of commercial Kapton ${ }^{\circledR}$ polyimide showed that treatment with base was necessary for adherence of the copper sulfide to the polymeric substrate. Preliminary experiments (Table I) revealed the necessity of pretreating the PI film with $\mathrm{NH}_{4} \mathrm{OH}$ at an elevated temperature to produce films that exhibited low surface electrical resistance.

Using variables of time, temperature, and $\mathrm{pH}$ of the incorporation reaction, a Box-Behnken design was carried out. The conditions corresponded to the chosen

TABLE II. Electrical resistance measurements of the CuS/Kapton ${ }^{\circledR}$ composites according to the Box-Behnken design. $x_{1}, x_{2}$, and $x_{3}$ represents the codified variables.

\begin{tabular}{rrrrcccc}
\hline \hline Test & $x_{1}{ }^{\mathrm{a}}$ & $x_{2}{ }^{\mathrm{b}}$ & $x_{3}{ }^{\mathrm{c}}$ & $T\left({ }^{\circ} \mathrm{C}\right)$ & $t(\mathrm{~h})$ & $\mathrm{pH}$ & $\begin{array}{c}\text { Electrical } \\
\text { resistance } \\
(\mathrm{ohms})\end{array}$ \\
\hline 1 & -1 & -1 & 0 & 70 & 1 & 2 & 3.8 \\
2 & -1 & 1 & 0 & 70 & 3 & 2 & 4.1 \\
3 & 1 & -1 & 0 & 80 & 1 & 2 & 1.7 \\
4 & 1 & 1 & 0 & 80 & 3 & 2 & 1.5 \\
5 & -1 & 0 & -1 & 70 & 2 & 1 & 4.8 \\
6 & -1 & 0 & 1 & 70 & 2 & 3 & 4.7 \\
7 & 1 & 0 & -1 & 80 & 2 & 1 & 1.2 \\
8 & 1 & 0 & 1 & 80 & 2 & 1 & 1.2 \\
9 & 0 & -1 & -1 & 75 & 1 & 1 & 2.4 \\
10 & 0 & -1 & 1 & 75 & 3 & 1 & 1.2 \\
11 & 0 & 1 & -1 & 75 & 3 & 3 & 2.2 \\
12 & 0 & 1 & 1 & 75 & 2 & 2 & 1.7 \\
13 & 0 & 0 & 0 & 75 & 2 & 2 & 1.7 \\
14 & 0 & 0 & 0 & 75 & 2 & 2 & 1.5 \\
15 & 0 & 0 & 0 & 75 & 2 & 2 & 1.7 \\
\hline \hline
\end{tabular}

${ }^{\mathrm{a}} x=(T-75) / 5$

${ }^{\mathrm{b}} x_{2}=t-2$.

${ }^{\mathrm{c}} x_{3}=\mathrm{pH}-2$. factorial design, and the resulting surface electrical resistances of polyimide/copper sulfide composites are illustrated in Table II. The composites present a low electrical surface resistance. Table III shows the main effects and interaction effects of the variables involved in the factorial design described in Table II. Among all the analyzed variables, the reaction time variable presented the highest influence on the value of surface electrical resistance. A strong interaction effect between the $\mathrm{pH}$ and time variables can also be observed. The main effect of the reaction time is maximized when the $\mathrm{pH}$ is maintained at a high level. To calculate a fitting response surface for the problem through the Box-Behnken design, we used a computer program of public domain. ${ }^{12,13}$ Equation (1) represents the fitting response surface. The analysis of variance was done using a model adequacy check, and the data are presented in Table IV. The equation, which describes the quadratic model, and the respective coefficient of standard errors are described as follows:

$$
\begin{aligned}
Y= & 1.633( \pm 0.066)-1.4125( \pm 0.040) x_{1} \\
& -0.2375( \pm 0.040) x_{2}+0.2500( \pm 0.040) x_{3} \\
& +1.0208( \pm 0.060) x_{1}{ }^{2}+0.1208( \pm 0.060) x_{2}{ }^{2} \\
& +0.4458( \pm 0.060) x_{3}{ }^{2}-0.1250( \pm 0.057) x_{1} x_{2} \\
& +0.1500( \pm 0.057) x_{1} x_{3}+0.1000( \pm 0.057) x_{2} x_{3}
\end{aligned}
$$

where $x_{1}, x_{2}$, and $x_{3}$ are normalized variables according to Table II.

TABLE III. Main effect and interaction effect of variables from the factorial design described in Table II.

\begin{tabular}{lcr}
\hline \hline \multicolumn{1}{c}{ Variables } & Main effect \\
\hline$A=$ temperature & & -2.95 \\
$B=$ time & & 0.10 \\
$C=\mathrm{pH}$ & -0.43 \\
& Interaction effect & \\
\hline$A B$ & $A C$ & $B C$ \\
\hline-0.25 & +0.05 & 0.35 \\
\hline \hline
\end{tabular}

TABLE IV. Analysis of variance according to the Box-Behnken design. $^{\text {a }}$

\begin{tabular}{lcccc}
\hline \hline $\begin{array}{c}\text { Source of } \\
\text { variation }\end{array}$ & $\begin{array}{c}\text { Sums of } \\
\text { square }\end{array}$ & $\begin{array}{c}\text { Degrees of } \\
\text { freedom }\end{array}$ & $\begin{array}{c}\text { Mean } \\
\text { square }\end{array}$ & $\begin{array}{c}\text { Test } \\
F\end{array}$ \\
\hline Regression & 21.4549 & 9 & 2.3839 & \\
& & & & 9.8577 \\
Residues & 1.2091 & 5 & 0.2418 & \\
Lack of adjustmant & 1.1825 & 3 & 0.3942 & \\
& & & & 29.5618 \\
Pure error & 0.0267 & 2 & 0.0133 & \\
Total & 22.6640 & 14 & & \\
\hline \hline
\end{tabular}

a\% explicated variance $=94.6649 . \%$ maximum explicable variance $=$ 99.8823. 
The lower values of coefficient of standard errors, in relation to the coefficients of Eq. (1), indicate that the quadratic model is adequate to describe the response surface. Deriving this equation in relation to $x_{1}, x_{2}$, and $x_{3}$ (or $d Y / d x_{i}$ ) and taking $d Y / d x_{i}=0$ allows obtaining the values $x_{1}=0.84, x_{2}=1.67$, and $x_{3}=-0.062$ that correspond to the optimum point of the process, represented by $T=80^{\circ} \mathrm{C}, t=3.67 \mathrm{~h}$, and $\mathrm{pH}=1.4$, respectively. The expected value of surface electrical resistance obtained by Eq. (1) was $0.76 \mathrm{ohm}$. Composites obtained under these conditions showed values in the range of $0.9-1.0 \mathrm{ohm}$.

To demonstrate that the optimum point of the process, represented by $T=80^{\circ} \mathrm{C}, t=3.67 \mathrm{~h}$, and $\mathrm{pH}=1.4$, is not only to be used in commercial Kapton ${ }^{\circledR}$ polyimide film, several other noncommercial polyimides films were investigated. Surface electrical resistances that were obtained are shown in Table V. One can see that the values are the same order of magnitude as the composite $\mathrm{CuS} /$ Kapton ${ }^{\circledR}$. It can be observed, in the majority of the samples, that increasing the number of dipping processes caused the surface electrical resistance to decrease. The exception was found for the CuS/BTDA-ASD sample.

\section{A. $\mathrm{NH}_{4} \mathrm{OH}$ treatment of Kapton ${ }^{\circledR}$}

To determine if the base-promoted conversion of a surface layer of polyimide into a poly(amic acid) surface could be observed, the samples were examined using Fourier transform infrared-photoacoustic spectroscopy (FTIR/PAS). Spectra of the original polyimide film and the modified film were obtained (Fig. 1). Absorption bands characteristic of imide rings ${ }^{6,15-17}$ were observed at $1775,1730,1380$, and $725 \mathrm{~cm}^{-1}$ in the spectrum of the original film. Additional absorption bands were observed at 1250 and $820 \mathrm{~cm}^{-1}$ which represent an ether moiety ${ }^{16}$ and para-substituted phenyl rings, ${ }^{15}$ respectively. Characteristics absorption bands of the polyamide layer ${ }^{18,19}$ occurred at 1667 and $1540 \mathrm{~cm}^{-1}$, and the appearance of a $\mathrm{N}-\mathrm{H}$ stretching absorption mode at about $3250 \mathrm{~cm}^{-1}$ was observed, giving further evidence that the imide ring had been hydrolyzed. As pointed out by Stoffel et al., ${ }^{9}$ the

TABLE V. Electrical resistance values of CuS/polyimide composites obtained using the under optimum point conditions $\left(T=80^{\circ} \mathrm{C}, t=\right.$ $3.67 \mathrm{~h}, \mathrm{pH}=1.4)$.

\begin{tabular}{lccc}
\hline \hline \multicolumn{1}{c}{ Film } & $\begin{array}{c}{\left[\mathrm{NH}_{4} \mathrm{OH}\right]} \\
\left(\mathrm{mol} \mathrm{L}^{-1}\right)\end{array}$ & $\begin{array}{c}\text { No. of } \\
\text { dippings }\end{array}$ & $\begin{array}{c}\text { Electrical } \\
\text { resistance }(\Omega)\end{array}$ \\
\hline BDSDA/ODA & 1 & 1 & 3.3 \\
BDSDA/ODA & 1 & 2 & 2.5 \\
BTDA/ODA & 1 & 1 & 4.9 \\
BTDA/ODA & 1 & 2 & 1.6 \\
BTDA/ODA & 7.7 & 1 & 2.8 \\
BTDA/ODA-ASD & 1 & 1 & 6.2 \\
BTDA/ODA-ASD & 1 & 2 & 1.3 \\
\hline \hline
\end{tabular}

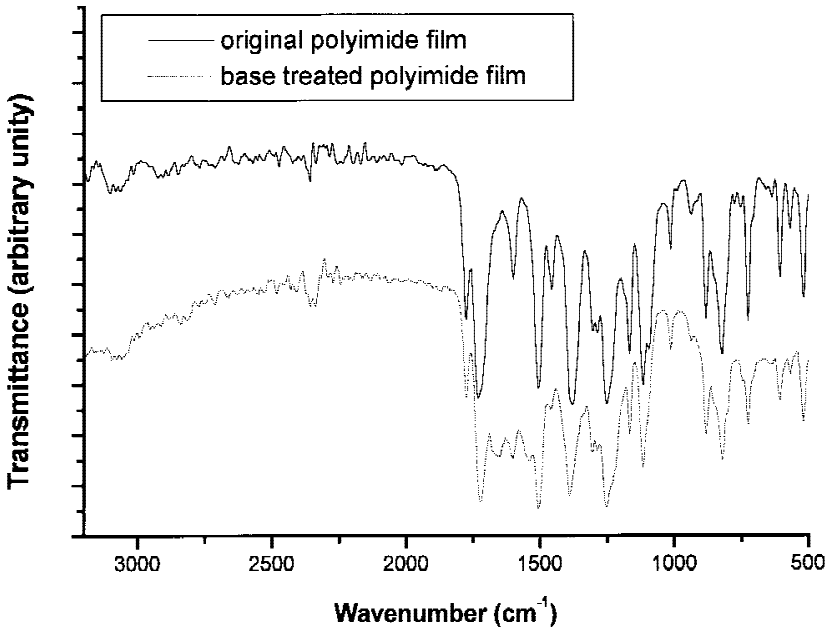

FIG. 1. PA-FTIR spectra of the (a) original and (b) base-treated Kapton ${ }^{\circledR}$ polyimide film.

modified layer should be penetrated by a subsequently deposited layer. This molecular interdiffusion should allow strong bonding to occur between layers, which is thus not susceptible to environmental degradation. ${ }^{9}$ The depth of the hydrolyzed surface layer grows roughly with base exposure. This is consistent with the idea that the layer growth kinetics is controlled by the chemical reaction at the interface which is situated between the basemodified layer and the underlying polyimide. Stoffel et al. ${ }^{9}$ have calculated the modification rate of Kapton ${ }^{\circledR}$, in $\mathrm{nm} / \mathrm{min}$, as a function of temperature for a $1 \mathrm{M} \mathrm{KOH}$ treatment. Using their relation, we may estimate that the depth of hydrolysis in our treatment reached about $1500 \mathrm{~nm}$.

To better understand the influence of the base treatment on the adhesion of copper sulfide particles to the polyimide film, XPS experiments on polyimide films with and without base treatment were carried out. The atomic concentration of the surface elements are indicated by the XPS profile [Fig. 2(a)]. In a comparison of the measured values of $\mathrm{C}(1 s), \mathrm{O}(1 s)$, and $\mathrm{N}(1 s)$ with the theoretical values, considering a monomeric unit of $22 \mathrm{C}$, $5 \mathrm{O}$, and $2 \mathrm{~N}$, it can be stated that the imidization was not complete. As pointed out by Leary and Campbell ${ }^{20}$ and Russat, ${ }^{21}$ a definitive description of the nature of the surface of commercial films is difficult due to the extremely complex character of polyamide-polyimide chemistry. The nonstoichiometric character of the surface can be due to (i) side reactions that produce residues of uncyclized polyamide acid in the final product and (ii) polymer fragments which are present in the surface region that result from hydrolytic scission of polyamide acid units by water of imidization. This explanation accounts for the differences that we observed concerning a larger experimental content of carbon and oxygen in relation to nitrogen when comparing the theoretical and 

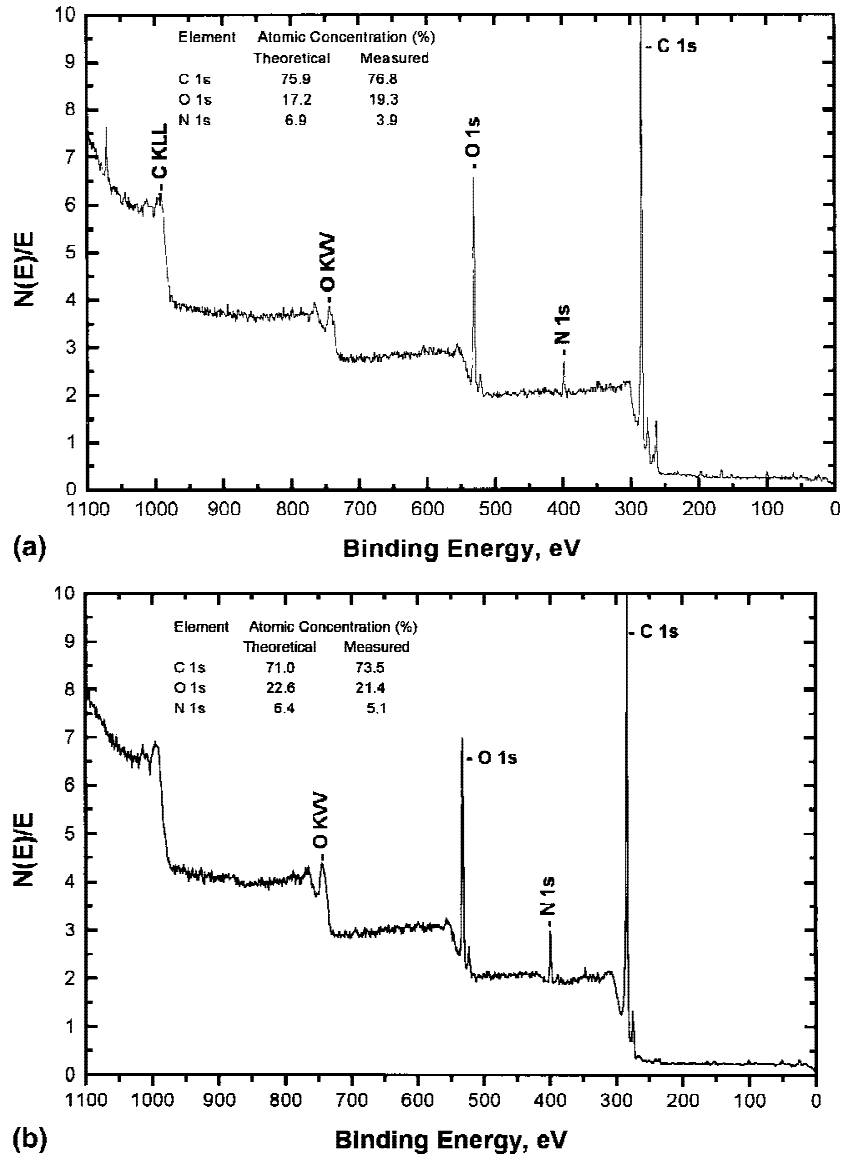

FIG. 2. XPS profiles of the (a) original and (b) base-treated Kapton ${ }^{\circledR}$ polyimide film. experimental values. The data presented in Fig. 2(b) show agreement with the results published by Stoffel et $a l .{ }^{9}$ and Lee et al. ${ }^{7}$ who observed the conversion of surface polyimide film to poly(amide acid).

The chemical states of carbon and oxygen were of interest. Curve-fitting of these elements is shown in Fig. 3. We have interpreted the fitting results with the help of available published data. ${ }^{22-27}$ Computed absolute binding energies (BE's) and integrated intensities of resolved $\mathrm{C}(1 s), \mathrm{N}(1 s)$, and $\mathrm{O}(1 s)$ for the original and basetreated Kapton ${ }^{\circledR}$ samples are reported in Table VI. As can be visualized, a decrease exists in the atomic concentration of carbon bonded to other carbons or hydrogen to $284.6 \mathrm{eV}$ from $49.3 \%$ to $42.8 \%$ upon comparing the original Kapton ${ }^{\circledR}$ to the base-treated one. We can also verify an increase in the percentage of "partially oxidized" carbon from $43.4 \%$ to $45.8 \%$. Associated with this increase is an increase of $4.1 \%$ in amide-carbonyl and acid-carbonyl carbons. The appearance of the oxygen peak at $534.2 \mathrm{eV}$ is in agreement with the relative data on the opening of imide cycles.

Complete drying of polyimide is extremely difficult $^{28,29}$ after partial hydrolysis. Data from the literature show that polyimide (e.g., PMDA/ODA) cured up to $125{ }^{\circ} \mathrm{C}$ presents a peak located at $535.0 \mathrm{eV}$ that is attributed to the $\mathrm{O}(1 s)$ of entrapped $\mathrm{H}_{2} \mathrm{O} .^{21}$ Our XPS data from original Kapton ${ }^{\circledR}$ are typical of the PMDA/ODA system already described in the literature. ${ }^{20,29-31}$ Therefore, when the polyimide was submitted to hydrolysis, we observed the opening of the imide cycle which means that the polyamide salt was formed. This can be compared to the data from the literature, ${ }^{21}$ where PMDA/ODA poly(amide acid) was completely imidized. In this way, part
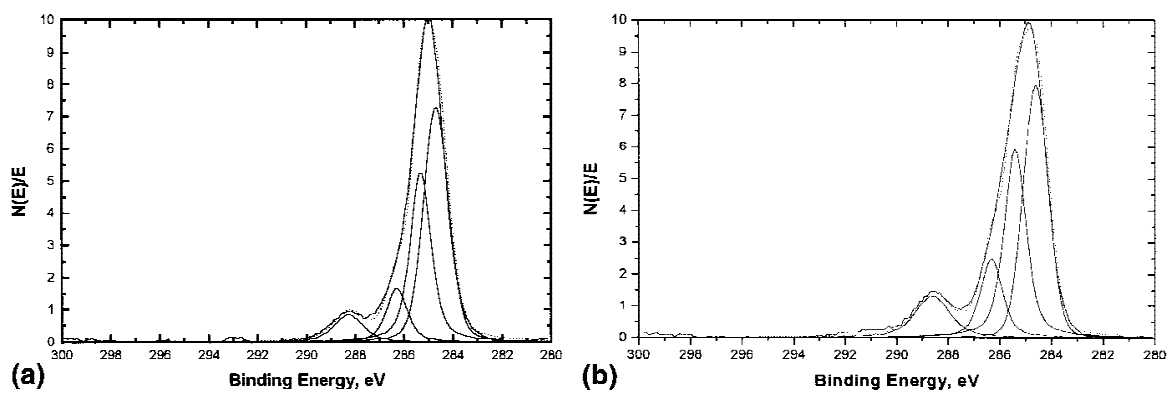

(b)

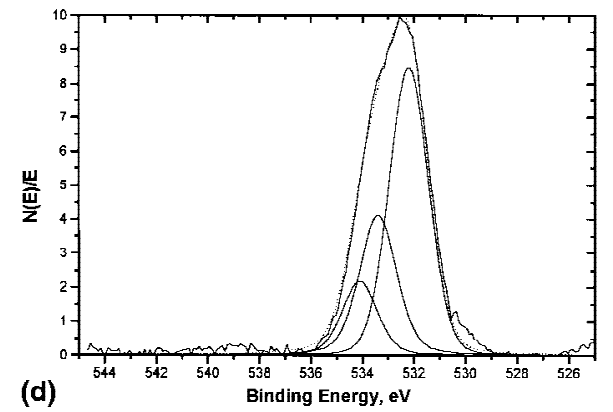

FIG. 3. Carbon (1s) XPS photopeaks of (a) original and (b) base-treated and oxygen (1s) photopeaks of (c) original and (d) base-treated Kapton ${ }^{\circledR}$ polyimide film. 
of the amide and acid functionalities were not imidized, which increased the "partially oxidized" carbon (i.e., the amide-carbonyl and the acid-carbonyl carbon contents) content.

\section{B. Surface characterization of composites films}

The XPS spectra of the CuS/Kapton ${ }^{\circledR}$ composite films with low-surface electric resistance are shown in Fig. 4, and the atomic concentrations of elements on the surface are indicated by the XPS profile (upper part of the figure). The binding energies and atomic concentrations of different species of the elements of carbon, oxygen, sulfur, and copper in the composite polyimide films are shown in Table VII. The XPS spectra of $\mathrm{Cu}$ and $\mathrm{S}$ in the composites are shown respectively in Figs. 5(a) and 5(b). The copper peak intensity remained constant, when the composite was sonicated as verified by Fig. 5(a). The sulfur peak intensity, on the other hand, at approximately $168.6 \mathrm{eV}$ decreased when the film was sonicated. This is probably due to the release of sulfate sulfur which slightly adhered to the surface.

The detected amount of nitrogen on the surface of the composite was very low. As may be observed in Fig. 5(b), the $\mathrm{S}(2 p)$ peak intensity at $168.6 \mathrm{eV}$ decreased in relation to the peak at $162.6 \mathrm{eV}$ which is due to the sulfur in the copper sulfide form. This copper sulfide, as already emphasized, is generated in the colloidal form, and it presents a negative charge. ${ }^{10,32,33}$ It is believed to interact with the part of the polyimide that was hydrolyzed and acquired positive charge, through the protonation of the nitrogen of the amide, because the copper sulfide was generated in acid media. At this point we may postulate that the interaction between the copper sulfide and amide group through nitrogen really happens and the growth of copper sulfide layer is responsible for the low surface concentration of nitrogen. In that way this part of the polyimide, associated with the copper sulfide, is closer to the surface that characterizes the increase of the "partially oxidized" carbons and we should

TABLE VI. Comparative XPS data.

\begin{tabular}{|c|c|c|c|c|}
\hline \multirow[b]{2}{*}{ Element } & \multicolumn{2}{|c|}{ Original Kapton ${ }^{\circledR}$} & \multicolumn{2}{|c|}{$\begin{array}{c}\text { Kapton }{ }^{\circledR} \text { with } \mathrm{NH}_{4} \mathrm{OH} \\
\quad\left(1 \mathrm{~mol} \mathrm{~L}^{-1}\right)\end{array}$} \\
\hline & $\begin{array}{c}\mathrm{BE} \\
(\mathrm{eV})\end{array}$ & $\begin{array}{c}\text { Atomic } \\
\text { concentration }(\%)\end{array}$ & $\begin{array}{c}\mathrm{BE} \\
(\mathrm{eV})\end{array}$ & $\begin{array}{c}\text { Atomic } \\
\text { concentration }(\%)\end{array}$ \\
\hline \multirow[t]{4}{*}{$\mathrm{C}$} & 284.6 & 49.3 & 284.6 & 42.8 \\
\hline & 285.3 & 33.2 & 285.4 & 32.2 \\
\hline & 286.2 & 10.2 & 286.3 & 13.6 \\
\hline & 288.2 & 7.3 & 288.6 & 11.4 \\
\hline \multirow[t]{3}{*}{$\mathrm{O}$} & 531.9 & 63.0 & 532.2 & 57.4 \\
\hline & 533.1 & 37.0 & 533.4 & 28.4 \\
\hline & $\cdots$ & $\cdots$ & 534.2 & 14.2 \\
\hline $\mathrm{N}$ & 399.8 & 100 & 400.1 & 100 \\
\hline
\end{tabular}

expect an increase in the peak of the amide-carbonyl and acid-carbonyl carbons for 288.5-289.2 eV. This increase really appears because the sum of the peaks at 287.2 and $288.4 \mathrm{eV}$ is practically twice the value found of $288.1 \mathrm{eV}$
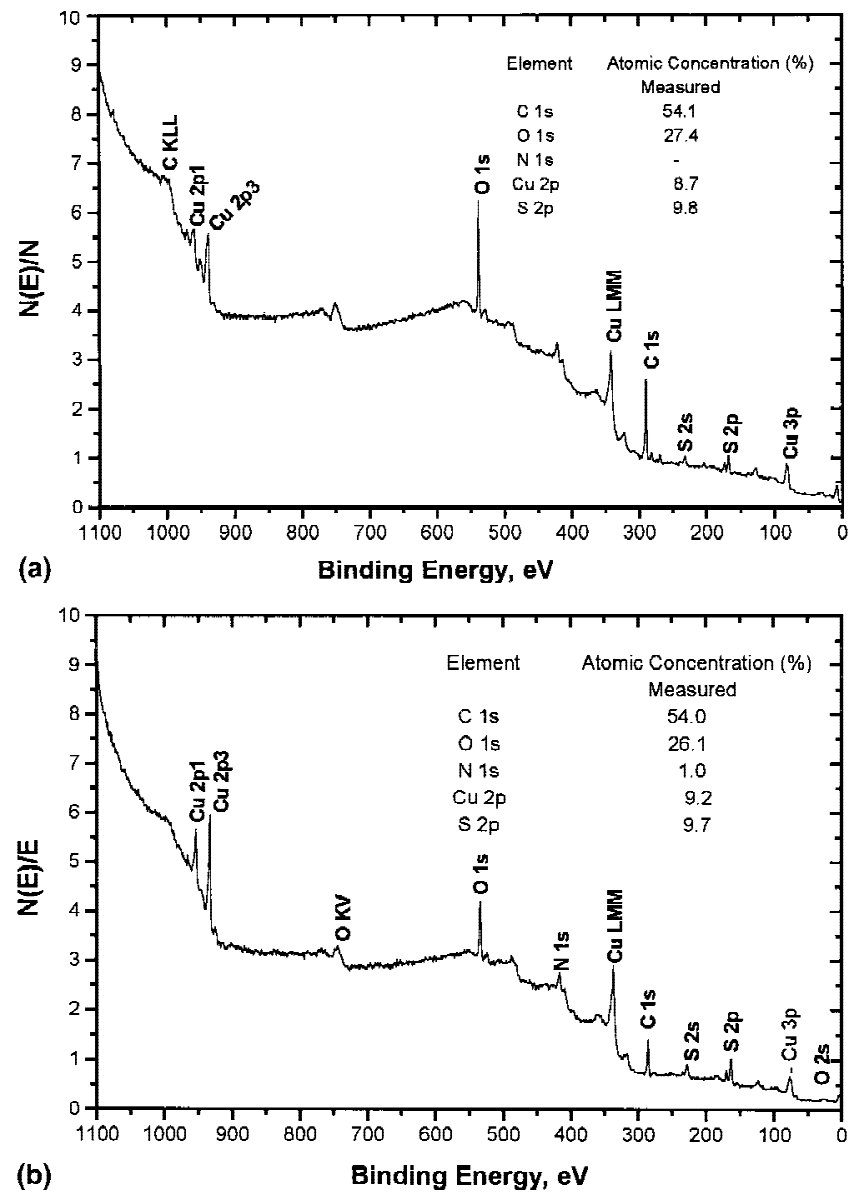

FIG. 4. XPS profiles of the CuS/Kapton ${ }^{\circledR}$ composites that were (a) not sonicated and (b) sonicated.

TABLE VII. Comparative XPS data.

\begin{tabular}{lccccc}
\hline \hline & \multicolumn{2}{c}{ CuS/Kapton ${ }^{\circledR}$ nonsonicated } & & \multicolumn{2}{c}{ CuS/Kapton ${ }^{\circledR}$ sonicated } \\
\cline { 2 - 3 } \cline { 5 - 6 } Element & $\begin{array}{c}\mathrm{BE} \\
(\mathrm{eV})\end{array}$ & $\begin{array}{c}\text { Atomic } \\
\text { concentration }(\%)\end{array}$ & & $\begin{array}{c}\mathrm{BE} \\
(\mathrm{eV})\end{array}$ & $\begin{array}{c}\text { Atomic } \\
\text { concentration }(\%)\end{array}$ \\
\hline $\mathrm{C}(1 s)$ & 284.6 & 75.5 & & 284.6 & 64.8 \\
& 285.9 & 17.8 & & 285.9 & 22.1 \\
& $\ldots$ & $\ldots$ & 287.2 & 7.3 \\
& 288.1 & 6.7 & & 288.4 & 5.8 \\
$\mathrm{O}(1 s)$ & 532.1 & 67.4 & & 532.3 & 69.7 \\
& 533.1 & 32.6 & & 533.5 & 30.3 \\
$\mathrm{~N}(1 s)$ & 400.0 & 100 & & 400.1 & 100 \\
$\mathrm{Cu}(2 p)$ & 932.9 & $\ldots$ & & 932.9 & $\ldots$ \\
& 944.9 & $\ldots$ & 944.0 & $\ldots$ \\
& 953.1 & $\ldots$ & 953.2 & $\ldots$ \\
$\mathrm{S}(2 p)$ & 963.6 & $\ldots$ & 964.0 & $\ldots$ \\
& 162.6 & $\ldots$ & 162.2 & $\ldots$ \\
\hline \hline
\end{tabular}


for the nonsonicated sample. The interaction of this part (amide-carbonyl and acid-carbonyl) of the polyimide with the copper sulfide can be better visualized by the appearance of the peak at $287.2 \mathrm{eV}$. Data from the literature $^{34}$ show that the interaction between copper and carbonyl is possible to occur through the electrons transfer from the copper to the carbonyl with displacement of the carbonyl peak from 289.2 to $287.7 \mathrm{eV}$. These interactions induce a displacement of the carbonyl oxygen peak to higher energy value and consequent overlap with the oxygen present in the ether part of the polyimide.

The composite BTDA-ODA/CuS presented the lowest resistance value (Table $\mathrm{V}$ ) when the polyimide BTDAODA was previously treated with $1 \mathrm{M} \mathrm{NH}_{4} \mathrm{OH}$, and it was twice dipped into the solution to obtain the copper sulfide deposition. The atomic concentration values of the elements on the surface for BTDA-ODA and for BTDA-ODA/CuS composite are shown in Table VIII. The experimental values for BTDA-ODA are practically the same as the theoretical ones. This indicates that the polyimide was completely imidized. The values of $\mathrm{Cu}$ and $\mathrm{S}$ for the composite are of the same magnitude and

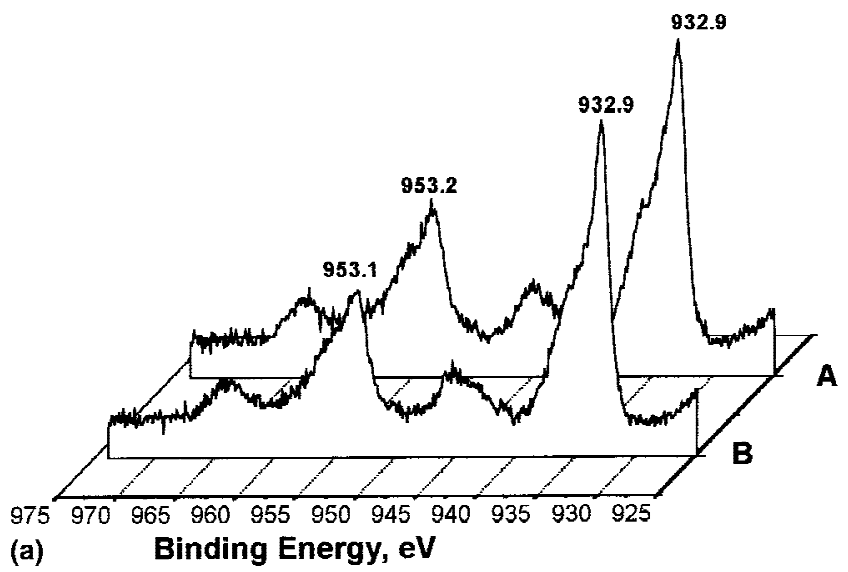

(a)

Binding Energy, eV

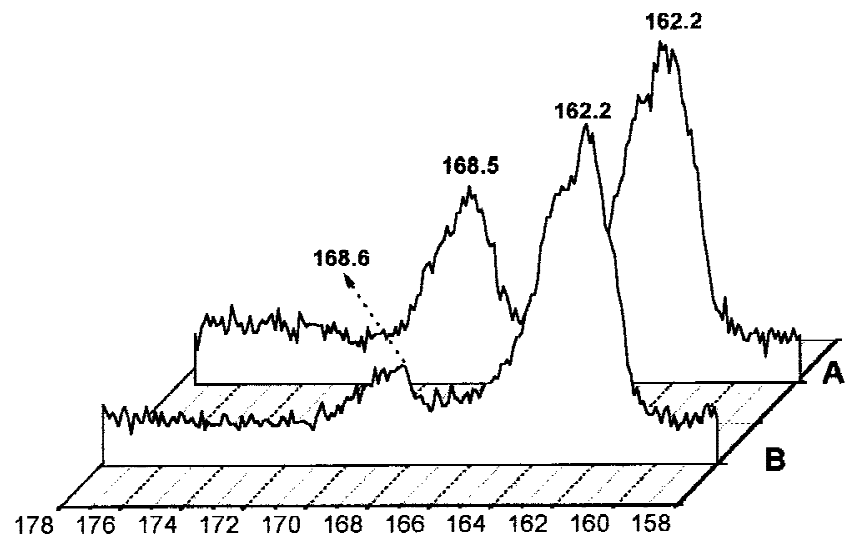

\section{(b) Binding Energy, eV}

FIG. 5. (a) Copper (2p) and (b) sulfur (2p) XPS photopeaks of the CuS/Kapton ${ }^{\circledR}$ composites: (A) nonsonicated; (B) sonicated. thus indicate the formation of $\mathrm{CuS}$. This is in agreement with the data of the literature ${ }^{10}$ for the preparation conditions of the composites.

Analysis of the XPS spectra of the elements $\mathrm{C}(1 s)$ and $\mathrm{O}(1 s)$ present in the BTDA-ODA/CuS composite, compared to the $\mathrm{CuS} / \mathrm{Kapton}{ }^{\circledR}$ composite, allows one to verify a similar behavior for the two composites.

The XPS spectra of the elements $\mathrm{Cu}$ and $\mathrm{S}$ for the BTDA-ODA/CuS and $\mathrm{CuS} / \mathrm{Kapton}{ }^{\circledR}$ composites are shown respectively in Figs. 6(a) and 6(b). Comparing the spectra of $\mathrm{Cu}$ and $\mathrm{S}$ for the composite BTDA-ODA/CuS

TABLE VIII. Comparative XPS data.

\begin{tabular}{|c|c|c|c|}
\hline \multirow[b]{2}{*}{ Element } & \multicolumn{2}{|c|}{$\begin{array}{l}\text { BTDA-ODA } \\
\text { Atomic concentration }(\%)\end{array}$} & \multirow{2}{*}{$\begin{array}{c}\text { CuS/BTDA-ODA } \\
\text { Atomic concentration }(\%) \\
\text { measured }\end{array}$} \\
\hline & Theoretical & Measured & \\
\hline $\mathrm{C}(1 s)$ & 77.9 & 78.4 & 41.1 \\
\hline $\mathrm{O}(1 s)$ & 16.6 & 16.2 & 17.1 \\
\hline $\mathrm{N}(1 s)$ & 5.5 & 5.4 & $\ldots$ \\
\hline $\mathrm{Cu}(2 p)$ & $\ldots$ & $\ldots$ & 21.1 \\
\hline $\mathrm{S}(2 p)$ & $\ldots$ & $\ldots$ & 20.6 \\
\hline
\end{tabular}
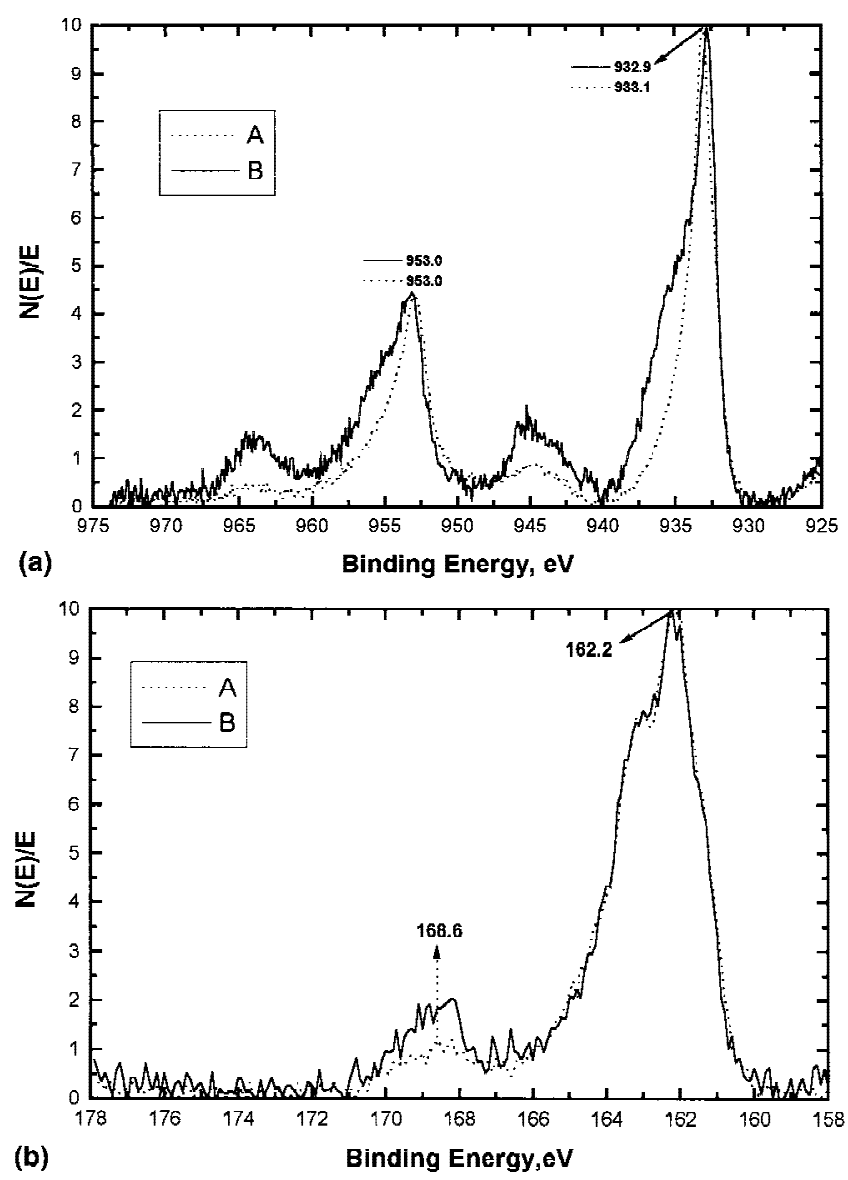

FIG. 6. (a) Copper ( $2 p)$ and (b) sulfur ( $2 p)$ of the (A) CuS/BTDAODA and (B) CuS/Kapton ${ }^{\circledR}$ composites. 
[Figs. 6(a.A) and 6(b.A)] with the spectra of $\mathrm{Cu}$ and $\mathrm{S}$ for the $\mathrm{CuS} / \mathrm{Kapton}^{\circledR}{ }^{\circledR}$ composite [Figs. 6(a.B) and 6(b.B)], respectively, we can verify that the intensity of the $S$ peaks at $168.6 \mathrm{eV}$, attributed to the sulfate or sulfone species, is lower for the BTDA-ODA/CuS composite. This evidences the smallest amount of this kind of adhered material. This is also evidenced by the largest amount of copper sulfide in these composites, around $20 \%$, when compared to the $\mathrm{CuS} / \mathrm{Kapton}{ }^{\circledR}$ composite whose found quantity is approximately $9 \%$. Data of the literature $^{35-39}$ show that satellites peaks are not observed for species contend $\mathrm{Cu}^{0}$ and $\mathrm{Cu}^{\mathrm{I}}$ and they become only observed for the species with $\mathrm{Cu}^{\mathrm{II}}$. The BTDA-ODA/ $\mathrm{CuS}$ composite presents the $\Delta E\left(2 p_{1 / 2}-2 p_{3 / 2}\right)$ of $19.9 \mathrm{eV}$. This value matches very well with data from the literature ${ }^{35}$ where the same value was found for CuS.

The x-ray diffraction pattern of CuS/Kapton ${ }^{\circledR}$ composite film, obtained from the optimized conditions described before, shows a diffraction pattern that can be indexed as $\mathrm{CuS}^{40}$ The characteristic $\mathrm{CuS}$ peaks were also observed in our laboratory in other polymer/CuS composite (for which the polymer substrate has no peak overlapping the $\mathrm{CuS}$ ones). As pointed out before, the surface electrical resistance of polyimide/copper sulfide decreases when the composite was prepared under the optimized conditions, obtained by RSM. These x-ray data and surface electrical resistance values matches very well with data from the literature for others polymer/CuS composites in which the conductivity increases from $\mathrm{Cu}_{2} \mathrm{~S}$ toward $\mathrm{CuS} .{ }^{10,41-43}$

\section{Thermal analysis}

Estimates of thermal stability for polyimide and composite films were obtained by performing thermal gravimetric analysis. As expected, the original Kapton ${ }^{\circledR}$ film demonstrated slightly higher thermal stability than the $\mathrm{CuS} /$ Kapton $^{\circledR}$ composite. The polymer decomposition temperature (PDT-10\%) for the original Kapton ${ }^{\circledR}$ film was $T=597{ }^{\circ} \mathrm{C}$ while that for the Kapton ${ }^{\circledR}$ for $\mathrm{CuS}$ composite film was $T=586^{\circ} \mathrm{C}$. The value of the glass transition temperature by differential scanning calorimetry was $370{ }^{\circ} \mathrm{C}$ for the original Kapton ${ }^{\circledR}$, in agreement with the value of $380{ }^{\circ} \mathrm{C}$ found by Stoffel et al. ${ }^{9}$ and also by Feger and Saraf. ${ }^{44}$ The CuS/Kapton ${ }^{\circledR}$ composite $\left(T_{\mathrm{g}}=375^{\circ} \mathrm{C}\right)$ did not present accentuated variation in the glass transition temperature when compared to the original film $\left(T_{\mathrm{g}}=370{ }^{\circ} \mathrm{C}\right)$. These data are in agreement to the work published by Rubira et al.,${ }^{14}$ where it is pointed out that silver-doped polyimide did not present any variation in the $T_{\mathrm{g}}$ when compared to the original polyimide Kapton ${ }^{\circledR}$. If one takes into account the experimental error in $T_{\mathrm{g}}$, no change appears in thermal stability when the copper sulfide was incorporated on the respective films.

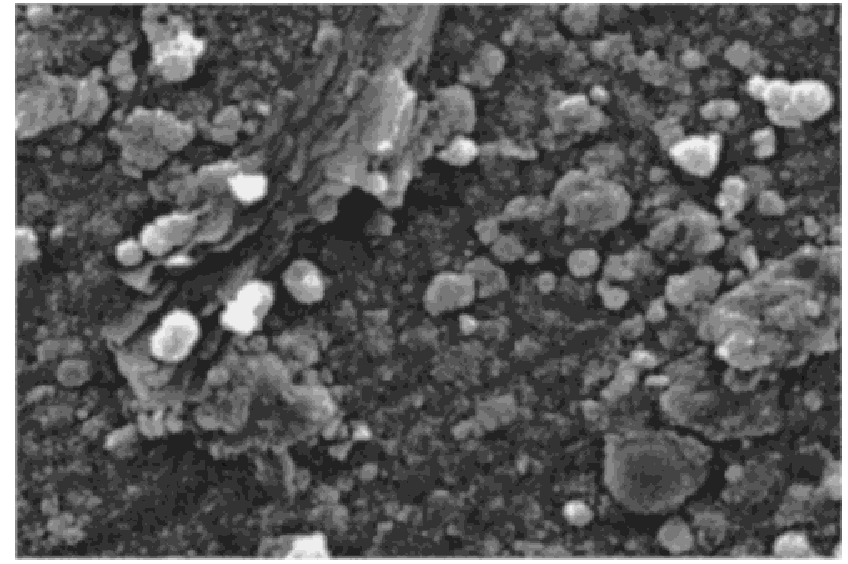

(a)

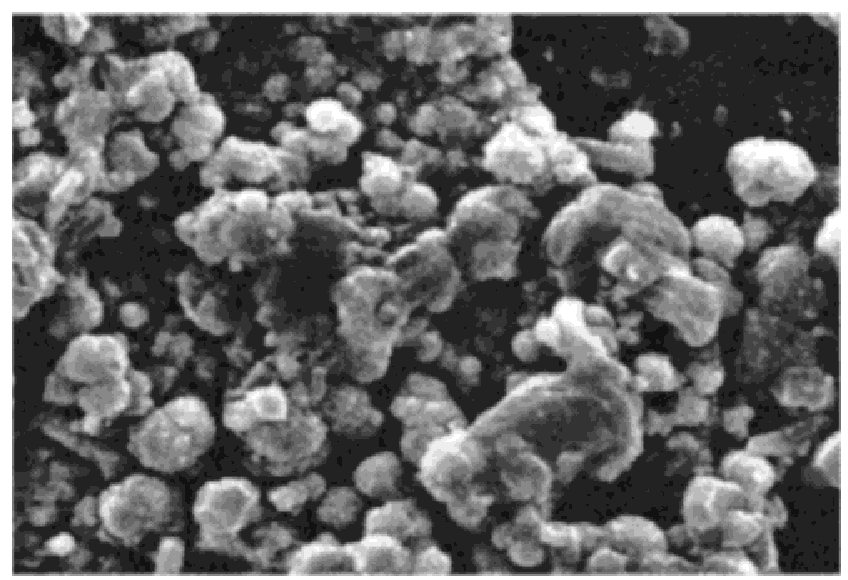

(b)

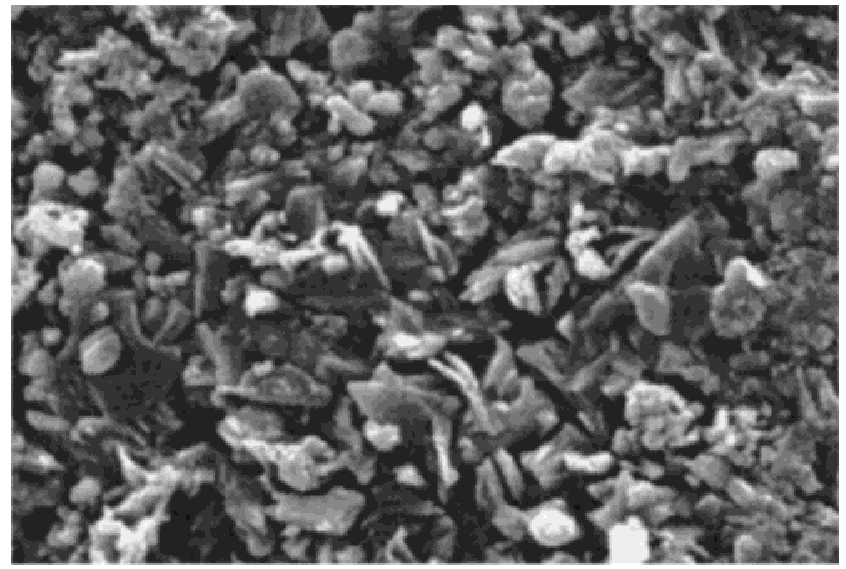

(c)

FIG. 7. Scanning electron microphotographs of the Kapton ${ }^{\circledR} / \mathrm{CuS}$ composites with different surface resistances: (a) $R=1 \mathrm{ohm}$; (b) $R=$ $300 \mathrm{ohm}$; (c) $R=1200 \mathrm{ohm}$.

\section{Microscopic analysis}

The modifications of the surfaces of polyimides were accompanied at macroscopic level by measures of XPS, as described in the previous section. However local differences at the microscopic level can be analyzed using 
SEM and AFM. The detailed analysis of the particles surface density and particles distribution in composites has been carried out to understand, on a molecular basis, the difference between the samples with high and low electrical resistances. Figure 7 illustrates microphotographs (5200× magnification) of CuS/Kapton ${ }^{\circledR}$ composite with different surface resistances. In that morphologic exam an almost total films overlaying was observed in a thick sulfide layer, being constituted from uniform sized particles. In Fig. 7(a) may be visualized an almost uniform base, without flaws, that reveals a continuity of the film, morphology that allows a good electrical conduction. In Figs. 7(b) and 7(c) it may be observed a lack of uniformity of the samples, with flaws. This nonuniformity causes strong influence in the electrical resistance, because the flaws and metallic sulfide behave as a phaseseparated structure. These data are in agreement to the work published by Rubira et al. ${ }^{45}$ They doped the polyimides BTDA/ODA and BDSDA/ODA with the addictive [Ag(COD)(HFA)], (1,5-cyclooctadiene)(hexafluoroacetylacetonato) silver(I), to obtain a film of metallic silver stuck on the polyimide surface. During this treatment the electric resistance of the surface of the BDSDA-ODA/Ag film became smaller. This material presented juxtaposed particles, in a continuous layer, as evidenced by the scanning electron microphotographs.
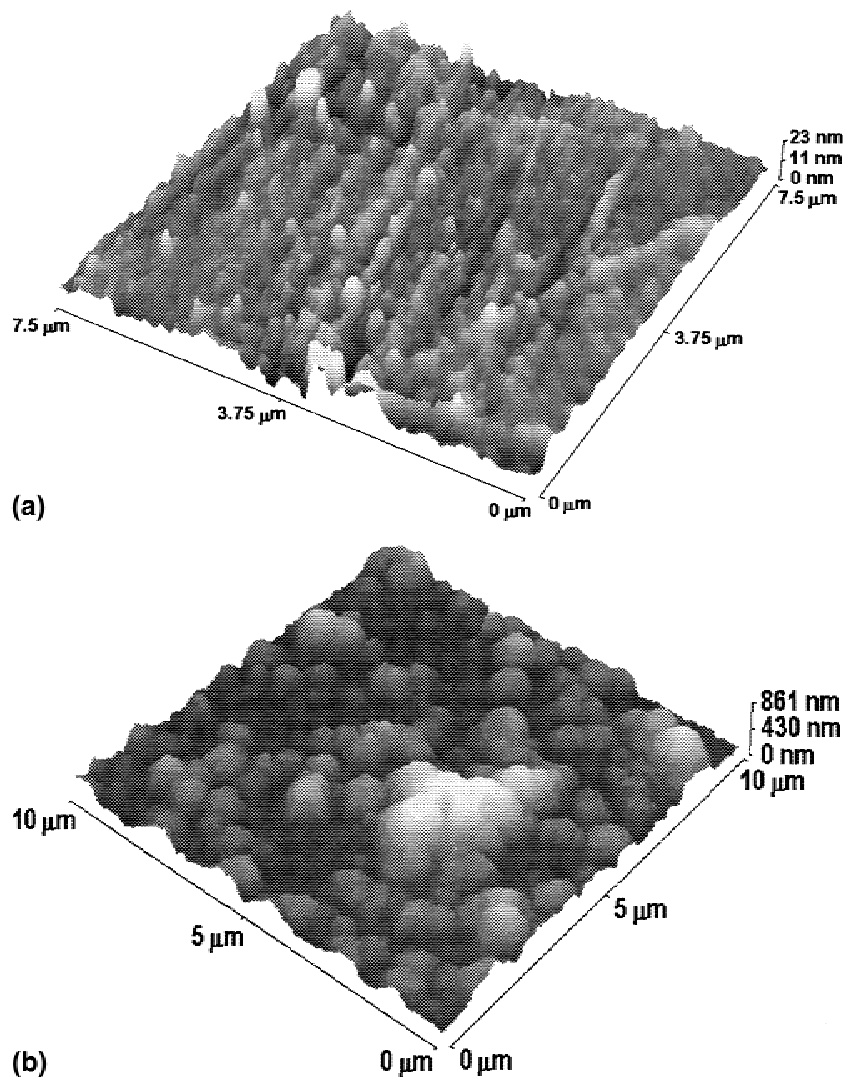

FIG. 8. Atomic force microscopy images of the (a) CuS/Kapton ${ }^{\circledR}(R=$ $1.2 \mathrm{ohm})$ and (b) CuS/BTDA-ODA:ASD $(R=1.3 \mathrm{ohm})$ composites.
The AFM images obtained on CuS/Kapton ${ }^{\circledR}$ film, with the resistance of $1.2 \mathrm{ohms}$, and on BTDA-ODA:ASD/ $\mathrm{CuS}$ film, with the resistance of $1.3 \mathrm{ohms}$., are presented in Figs. 8(a) and 8(b), respectively. The CuS/Kapton ${ }^{\circledR}$ composite [Fig. 8(a)] presents the growth of a quite homogeneous phase on the surface. The continuity of the copper sulfide on the film surface and the sizing uniformity, in that phase, were verified. In Fig. 8(b) a very uniform distribution of juxtaposed particles, similar to the CuS/Kapton ${ }^{\circledR}$ composite film [Fig. 8(a)], was achieved. It is in agreement with the expect structure when the optimized conditions, determined by the factorial design, are used.

\section{CONCLUSIONS}

Copper sulfide incorporation onto the surface of polyimide showed that treatment with base was necessary for adherence of the copper sulfide to the polymeric matrix. Using optimized conditions, polyimide/CuS with electrical resistance as low as $1.0 \mathrm{ohm}$ can be obtained. The incorporation of copper sulfide onto the polyimide surface was demonstrated by XPS. Homogeneous CuS distribution in all composite surfaces was observed by scanning electron microphotographs and by the images from atomic force microscopy.

\section{REFERENCES}

1. M.K. Ghosh and K.L. Mittal. Polyimides: Fundamentals and Applications, edited by M.K. Ghosh and K.L. Mittal (Marcel Dekker, New York, 1996).

2. A.M. Wilson. Thin Solid Films 83, 145 (1981).

3. C.J. Bartlet, J.M. Segelken, and N.A. Teneketges. IEEE Trans. Compon. Hybrids. Manuf. Technol. 12, 637 (1987).

4. D. Wilson, H.D. Stenzenberger, and P.M. Hergenrother. Polyimides, edited by D. Wilson, H.D. Stenzenberger, and P.M. Hergenrother (Blackie \& Son, Glasgow, United Kingdom, 1990).

5. D-Y. Shih, J. Paraszczak, N. Klymko, R. Flitsch, S. Nunes, J. Lewis, C. Yang, J. Cataldo, R. McGouey, W. Graham, R. Serino, and E. Galligan, J. Vac. Sci. Technol., A. 7, 1402 (1989).

6. T. Strunskus, M. Grunze, G. Kochendoerfer, and C.H. Wöll, Langmuir 12, 2712 (1996).

7. K.W. Lee, S.P. Kowalczyk, and J.M. Shaw, Macromolecules 23, 2097 (1990).

8. K.W. Lee, S.P. Kowalczyk, and J.M. Shaw, Langmuir 7, 2450 (1991).

9. N.C. Stoffel, M. Hsieh, S. Chandra, and E.J. Kramer, Chem. Mater. 8, 1035 (1996).

10. T. Yamamoto, K. Tanaka, E. Kubota, and K. Osakada, Chem. Mater. 5, 1352 (1993).

11. H. Hu, J. Campos, and P.K. Nair, J. Mater. Res. 11, 739 (1996).

12. D.C. Montgomery, Design and Analysis of Experiments, 4th ed. (John Wiley \& Sons, New York, 1997).

13. B. Barros Neto, I.S. Scarminio, and R.E. Bruns, Design and Optimization of Experiments (Unicamp, Campinas, Brazil, 1995).

14. A.F. Rubira, L.T. Taylor, J.D. Rancourt, A.K. St. Clair, and D.M. Stoakley, J. Mater. Sci.: Pure Appl. Chem. A35, 621 (1998). 
15. M. Navarre, in Polyimides: Synthesis, Characterization, and Applications, edited by K.L. Mittal (Plenum Press, New York, 1984), pp. $438-439$.

16. R.M. Silverstein, G.C. Bassler, and T.C. Morril, Spectrometric Identification of Organic Compounds, 4th ed. (John Wiley \& Sons, New York, 1981).

17. H. Ishida, S.T. Wellinghoff, E. Boer, and J.L. Koenig, Macromolecules 13, 826 (1980).

18. J.L. Koenig, Spectroscopy of Polymers (Amer. Chem. Soc., Washington, DC, 1993).

19. F.J. Boerio, J.T. Young, and W.W. Zhao, in Multidimensional Spectroscopy of Polymers (Amer. Chem. Soc., Washington, DC, 1995).

20. H.J. Leary and D.S. Campbell, Surf. Interface Anal. 1, 75 (1979).

21. J. Russat, Surf. Interface Anal. 11, 414 (1988).

22. H.J. Leary and D.S. Campbell, in Photon, Electron and Ion Probes of Polymer Structure and Properties, edited by D.W. Dwight, T.J. Fabish, and H.R. Thomas (Amer. Chem. Soc., Washington, DC, 1981).

23. J.R. Salem, F.O. Sequeda, J. Duran, W.Y. Lee, and R.M. Yang, J. Vac. Sci. Technol. A3, 739 (1985).

24. D.T. Clark and H.R. Thomas, J. Polym. Sci., Polym. Chem. Ed. 16, 791 (1978).

25. B.D. Silverman, P.N. Sanda, and P.S. Ho, J. Polym. Sci., Polym. Chem. Ed. 23, 2857 (1985).

26. P.L. Buchwalter and A.I. Baise, in Polyimides: Synthesis, Characterization, and Applications, edited by K.L. Mittal (Plenum Press, New York, 1984).

27. C.D. Wagner, W.M. Riggs, L.E. Davis, J.F. Moudler, and G.E. Muilemberg, Handbook of X-Ray Photoelectron Spectroscopy (Perkin-Elmer, Edima, MN, 1978).

28. S. Strauss and A. Wall, J. Res. Natl. Bur. Stand., Sect. A 63, 269 (1959).
29. K.S. Sengupta and H.K. Birnbaum, J. Vac. Sci. Technol. A9, 2928 (1991).

30. W.C. Stewart, J. Leu, and K.F. Jensem, in Interfaces between Polymers, Metals and Ceramics, edited by B.J. DeKoven, A.J. Gellman, and R. Rosemberg (Mater. Res. Soc. Symp. Proc. 153, Pittsburgh, PA, 1989), pp. 285-290.

31. C.E. Sroog, J. Polym. Sci. 11, 161 (1976).

32. T. Yamamoto, A. Taniguchi, K. Kubota, and Y. Tominaga, Inorg. Chim. Acta 104, L1 (1985).

33. S. Dev, A. Taniguchi, T. Yamamoto, K. Kubota, and Y. Tominaga, Colloid Polym. Sci. 265, 922 (1987).

34. A.J. Pertsin and Y.M. Pashunin, Appl. Surf. Sci. 47, 115 (1991).

35. M. Romand, M. Roubin, and J.P. Deloume, J. Electron Spectrosc. Relat. Phenom. 13, 229 (1978).

36. H. Tu and J. Wang, Polym. Degrad. Stab. 54, 195 (1996).

37. S. Bahadur and D. Gong, Wear 162-164, 397 (1993).

38. G. Schön, Surf. Sci. 35, 96 (1973).

39. T.N. Vorob'eva, Polym. Sci. 36, 1240 (1994).

40. JCPDS Database, No. 6-0464.

41. H. Grijalva, M. Inoue, S. Boggavarapu, and P. Calvert, J. Mater. Chem. 6, 1157 (1996).

42. I. Grozdanov and M. Najdoski, J. Solid State Chem 114, 469 (1995).

43. M. Küpper and J.W. Schultze, J. Electroanal. Chem. 427, 129 (1997).

44. C. Feger and R. Saraf, in Advances in Polyimide Science and Technology, edited by C. Feger, M. Khojasteh, and M.S. Htoo (Technomic Publishing, New York, 1991).

45. A.F. Rubira, J.D. Rancourt, M.L. Caplan, A.K. St. Clair, and L.T. Taylor, Chem. Mater. 6, 2351 (1994). 